\title{
Praanggapan pada dialog mengenai kejujuran: Kajian pragmatik dalam novel asal kau bahagia karya Bernard Batubara
}

\author{
Prapti Wigati Purwaningrum 1, *, Lia Nurmalia ${ }^{2}$ \\ Bahasa Inggris, Fakultas Komunikasi dan Bahasa, Universitas Bina Sarana Informatika \\ 1 prapti.pwp@bsi.ac.id *; ${ }^{2}$ lia.lnm@bsi.ac.id \\ *korespondensi penulis
}

\begin{tabular}{ll}
\hline Informasi artikel & \\
\hline Sejarah artikel: & \\
Diterima & 14 Januari 2019 \\
Revisi & 21 Maret 2019 \\
Dipublikasikan & 25 April 2019 \\
\hline
\end{tabular}

Kata kunci:

Praanggapan

Jenis praanggapan

Kejujuran

Novel asal kau bahagia

\begin{abstract}
ABSTRAK
Penelitian ini bertujuan untuk mengkaji praanggapan pada dialog mengenai kejujuran melalui kajian pragmatik. Ini merupakan penelitian kualitatif dengan metode analisis isi karena penelitian ini lebih mengutamakan pendekatan konten dari dialog dalam novel tersebut. Sumber data penelitian ini adalah teks berisi dialog yang mengandung praanggapan dan menyiratkan tentang kejujuran dalam Novel Asal Kau Bahagia karya Bernard Batubara. Penyediaan data dilakukan dengan menggunakan metode simak yang diterapkan melalui teknik catat. Hasil penelitian ini menunjukkan bahwa 26 data yang mengandung praanggapan yang terdiri dari 9 data termasuk dalam praanggapan faktif, 3 data praanggapan leksikal, 7 data sebagai praanggapan eksistensial 5 data praanggapan non-faktual, dan 2 data merupakan praanggapan konterfaktual. Selain itu penelitian juga menemukan beberapa praanggapan dalam novel tersebut tersirat adanya pesan bahwa dalam setiap tuturan, tindakan akan selalu berkaitan dengan nilai kejujuran, hanya saja kejujuran tersebut dapat dituturkan atau hanya tertahan sebagai niatan untuk dituturkan. Jika ini terjadi maka hanya prasangka dan dendam yang ada. Selain itu melalui kajian pragmatik, praanggapan, serta kejujuran ini penulis berharap hasil tulisan ini akan mampu memberikan sumbangan pemikiran terhadap masyarakat pembaca tentang pentingnya nilai kejujuran dalam persahabatan, percintaan, serta dalam masyarakat yang akhir-akhir ini sedikit memudar.
\end{abstract}

Key word:

Presupposition

Type of presupposition

Honesty

Asal kau bahagia novel

\begin{abstract}
The aims of this analysis is to examine presuppositions on dialogue about honesty through pragmatic studies. This is a qualitative study with content analysis method because this research prioritizes the content approach of dialogue in the novel. The data source of this analysis is a dialogues that contain presuppositions and imply honesty in the novel Asal Kau Bahagia by Bernard Batubara. Data provision of this analysis is done by using simak method that is applied through note-taking techniques. The results of this study indicate that 26 data containing presuppositions consisting of 9 data included in factive presuppositions, 3 lexical presuppositions data, 7 data as existantial presuppositions, 5 data as non-factual presuppositions, and 2 data are counterfactual presuppositions. In addition, the research also revealed that through several presupposition there was a message in each speech, the action would always be related to the value of honesty, but sometime it is really to be said. If it happens there is only prejudice and revenge exists. In addition, through this pragmatic, presupposition, and about honesty, the author also hopes that the results of this paper will be able to contribute ideas to the reading community about the importance of the value of honesty in friendship, romance, and in a society that has recently faded.
\end{abstract}

Copyright (C) 2019 Universitas Ahmad Dahlan.

\section{Pendahuluan}

Pragmatik merupakan kajian yang mampu mengakomodasi beberapa aspek di luar bahasa yang dapat memberikan makna dalam sebuah tuturan. Salah satu kajian pragmatik yang cukup menarik untuk diteliti adalah praanggapan. Praanggapan merupakan sesuatu yang dapat diasumsikan oleh penutur sebelum menghasilkan sebuah tuturan (Yule, 1996). Berbagai asumsi terhadap sesuatu hal dapat muncul karena penutur atau pembaca belum 
mengetahui maksud dari apa yang sedang dilihat atau dibaca. Seperti dalam sebuah novel, terkadang ada pesan atau tuturan yang tidak disampaikan secara tersurat dalam sebuah novel, maka diperlukan pemahaman lebih tentang praanggapan agar maksud dalam novel tersebut dapat dipahami. novel merupakan sebuah karya sastra yang cukup baik dan juga rumit untuk dipahami. Dengan demikian penulis ingin melalui kajian ini akan memudahkan pembaca memahami dengan lebih dalam terhadap sebuah novel melalui praanggapan. Tidak jarang pembaca ikut terhanyut dan bahkan berimajinasi melalui alur cerita tersebut, karena mereka sangat memahami dan mendalami kata demi kata hingga tuturan yang mampu membius pikiran. Semua itu tidak lepas dari bahasa dan makna yang terkandung di dalamnya serta simbol-simbol yang mewakili pesan yang akan disampaikan oleh penulis novel tersebut. Namun terkadang ada beberapa pesan atau makna yang disampaikan secara tersirat oleh penulis dengan maksud tertentu. Terkadang tidak mudah bagi pembaca untuk dapat memahami alur cerita dalam novel, maka dibutuhkan kemampuan untuk menangkap pesan yang terkadang secara tersirat ada dibalik setiap tuturan yang dituturkan oleh para karakter dalam novel tersebut. Setiap tuturan yang ada dalam novel tidak hanya sekedar menyuratkan sesuatu tetapi juga ada maksud lain yang ingin disampaikan yang berkaitan dengan alur cerita. Untuk memahami sebuah makna yang tersirat dalam sebuah tuturan diperlukan ranah ilmu untuk mengkajinya yaitu pragmatik.

Menurut (Purwo, 1984) Pragmatik sebagai telaah mengenai makna tuturan melalui sebuah konteks. Melalui pragmatik pembaca tidak hanya sekedar mengetahui makna tersurat tetapi juga makna tersirat dari tuturan yang erat kaitannya dengan konteks pada saat tuturan tersebut dituturkan. Pendapat lain juga disampaikan oleh (Wijana, I.D.P, 2009) dalam Roses komunikasi akan melibatkan percakapan antara penutur dan petutur dalam menyampaikan sebuah informasi atau peristiwa tutur melalui sebuah konteks. Dengan demikian konteks menjadi sesuatu yang penting saat seseorang akan memahami sebuah tuturan.

Untuk memahami suatu maksud dalam sebuah tuturan diperlukan pemahaman dalam sebuah konteks. Dalam memahami sebuah bacaan khususnya dalam hal ini novel pembaca membutuhkan kemampuan untuk mencerna atau adanya anggapan dasar terhadap konteks, dengan demikian pembaca lebih dapat menikmati alur cerita dan bahkan ikut serta hanyut didalamnya. Selain konteks pemahaman terhadap praanggapan juga berperan penting di dalamnya.

Menurut (Yule, 1996), praanggapan merupakan apa yang digunakan penutur sebagai dasar bersama bagi para peserta percakapan. Pendapat lain juga diungkapkan oleh (Rahardi, 2005) sebuah tuturan dapat dikatakan mempraanggapkan tuturan yang lain apabila ketidakbenaran tuturan yang diproposisikan mengakibatkan ketidakbenaran atau kebenaran. Praanggapan merupakan suatu tuturan yang mengandung makna kebenaran atau ketidakbenaran sesuai dengan tuturannya.

Kejujuran merupakan sebuah kekayaan yang dimiliki oleh individu yang melekat dalam setiap sikap dan tingkah laku (Suparno P, 2003). Dalam (KBBI, 2008) kejujuran merupakan kata sifat yang berarti keadaan jujur, ketulusan dan kelurusan hati. Untuk mengungkapkan sebuah kejujuran diperlukan keberanian dan kemantapan hati bahwa apa yang akan dituturkan adalah benar, baik, dan akan berguna. Menurut Suparno dalam (Kusmiyati, 2013) yang dipublikasi di Kompasiana menuliskan bahwa kejujuran adalah sesuatu yang dilakukan sesuai hati dan norma.

Novel terbaru dengan judul Asal Kau Bahagia yang ditulis oleh Bernard Batubara, cerita dalam novel ini terinspirasi dari lagu dengan judul yang sama dan dipopulerkan oleh band Armada. Belum lama ini cerita dalam novel tersebut diangkat ke layar lebar dengan judul yang sama dan cukup menyita perhatian para penikmat film di Indonesia. Cerita dalam novel tersebut mengisahkan tentang perjalanan cinta sepasang kekasih Radha dan Tasya. Tasya merupakan cewek popular sedangkan Radha hanya seorang yang lugu, cupu dan setia. Sepanjang hubungan mereka Radha selalu menyangsikan keputusan Tasya untuk menerimanya sebagai kekasih, hingga suatu saat sebuah kecelakaan yang menyebabkan Radha koma dan akhirnya meninggal. Dalam komanya arwah Radha yang sempat tertahan tidak sengaja melihat Tasya dengan Erick, laki-laki yang begitu sempurna dimata Tasya yang mampu mengalihkan sedikit hati Tasya untuk Radha. Saat Radha tersadar dari koma, dia memutuskan untuk merelakan Radha pergi darinya karena rasa cintanya yang ingin selalu melihat Tasya bahagia. Setelah Tasya mengetahui keputusan Radha melalui rekaman yang telah Radha buat, saat itu juga Tasya mendengar kabar bahwa Radha telah meninggal.

Dalam novel "Asal Kau Bahagia" ini Bernard Batubara sebagai penulis novel ingin menyampaikan pesan mengenai pentingnya sebuah kejujuran dan ketulusan dalam sebuah hubungan. Ada sebuah 
rahasia yang disembunyikan oleh Tasya pada Radha, yang akhirnya hal ini menjadi seperti bom waktu yang siap menghancurkan Radha setiap saat. Penulis melakukan kajian secara pragmatik untuk mengetahui makna tersirat dalam novel Asal Kau Bahagia, melalui kajian praanggapan tentang kejujuran yang tersirat dalam novel tersebut. Analisis ini menjadi penting karena dapat memberikan pemahaman lebih tentang novel ini secara khusus dan penerapan teori pragmatik serta praanggapan dalam sebuah karya sastra. Hal ini juga dapat memberikan referensi pada peneliti lain dalam ranah kajian yang lain.

Penelitian tentang praanggapan pernah dilakukan oleh (Andryanto, S.F., Andayani, Rohmadi, 2014) berjudul "Analisis praanggapan pada percakapan tayangan "SKETSA" di Trans TV" yang meneliti tentang tindak tutur dan juga praanggapan. Penelitian tersebut menyimpulkan bahwa penggunaan praanggapan muncul pada beberapa tuturan dalam sketsa tersebut, praanggapan terjadi karena adanya persamaan pengetahuan (knowledge background) yang disalah artikan dengan sesuatu hal yang sama, tetapi menjadi memiliki makna yang berbeda pada saat lawan tutur kurang memahami dan mencermati tuturan dari penutur tersebut.

Penelitian lain yang berkaitan dengan praanggapan juga pernah dilakukan oleh (Retnosari, 2014) dengan judul "Praanggapan dan Implikatur dalam Mr. Pecut Pada Jawa Pos" melalui tulisannya menyimpulkan bahwa praanggapan yang tepat dapat mempertinggi nilai komunikatif sebuah ujaran yang diungkapkan. Semakin tepat praanggapan dihipotesiskan makin tinggi nilai komunikasi suatu ujaran.

Selain itu penelitian serupa tentang praanggapan dan implikatur juga telah dilakukan oleh (Wijayanti, 2016) dengan judul "Presuposisi dan Implikatur Pada Stand Up Comedy Indonesia" dalam tulisannya disimpulkan bahwa presuposisi dalam sebuah ujaran dibangun untuk menyampaikan kondisi geografis, pendidikan masyarakat, perkembangan teknologi, dan tentang makanan. Implikatur digunakan untuk mengaku kekurangan pribadi, keinginan mendapatkan perhatian dari pemerintah, dan mengkritik pemerintah.

Dari penjelasan tersebut dapat diketahui bahwa pembahasan presuposisi atau praanggapan dan implikatur menjadi sebuah pembahasan yang sangat menarik namun dari ketiga penelitian tersebut praanggapan masih dalam lingkup yang sempit dalam artian antara penutur dan petutur. Sedangkan penelitian yang saat ini penulis lakukan yaitu praanggapan yang muncul dalam tuturan dalam novel Asal Kau Bahagia dikaitkan dengan makna kejujuran yang muncul menjadi sesuatu yang berbeda dan memberikan manfaat tentang arti sebuah kejujuran.

\section{Metode}

\section{Pendekatan penelitian}

Pendekatan yang digunakan dalam penelitian ini adalah kualitatif. Metode penelitian yang digunakan adalah analisis isi karena penelitian ini lebih mengutamakan pendekatan konten dari dialog dalam novel "Asal Kau Bahagia" karya Bernard Batubara. Penulis memilih novel tersebut karena ceritanya ringan, mudah dipahami, terinspirasi dari lagu yang cukup fenomenal dan yang terpenting banyak terdapat tuturan yang mengandung praanggapan yang jika dipahami secara mendalam maka pembaca akan dapat memahami runtutan cerita serta pesan yang ingin disampaikan dalam novel tersebut. Data penelitian berupa penggalan dialog dalam novel tersebut.

\section{Proses penyediaan data}

Menurut Sudaryanto (2015) ada dua metode penyediaan data yaitu metode simak dan cakap. Pada penelitian ini penulis menggunakan metode simak untuk proses penyediaan data. Metode ini dipilih karena objek yang diteliti berupa teks yang berupa dialog. Untuk menerapkan metode tersebut penulis menggunakan teknik catat untuk mencatat tuturan dalam dialog yang mengandung praanggapan. Sumber data penulisan ini adalah novel "Asal Kau Bahagia" yang ditulis oleh Bernard Batubara penyediaan data dilakukan dengan membaca novel, mengidentifikasi tuturan yang mengandung praanggapan lalu mengelompokkannya berdasarkan tipe praanggapan.

\section{Hasil dan pembahasan}

Hasil penelitian menunjukkan bahwa praanggapan faktual adalah jenis praanggapan yang paling sering muncul dalam novel Asal Kau Bahagia karya Bernard Batubara, sedangkan praanggapan struktural tidak pernah muncul, $\mathrm{Hal}$ ini menunjukkan bahwa ternyata praanggapan jenis faktual ini dapat membantu pembaca memahami lebih dalam sebuah alur cerita dengan mengasumsikan sesuatu yang dituturkan oleh setiap karakter untuk dapat diterima dengan penarikan dari praanggapan yang muncul sebagai informasi yang ingin disampaikan. Berikut beberapa temuan dalam penelitian mengenai praanggapan yang disajikan pada tabel 1. 
Tabel 1: Jenis praanggapan pada novel Asal Kau Bahagia

\begin{tabular}{|c|c|c|c|c|c|c|}
\hline \multirow{2}{*}{$\begin{array}{c}\text { Juml } \\
\text { ah } \\
\text { Data }\end{array}$} & \multicolumn{6}{|c|}{ Jenis Praanggapan } \\
\hline & $\begin{array}{c}\text { Eksis } \\
\text { tensia } \\
1\end{array}$ & $\begin{array}{c}\text { Fakt } \\
\text { ual }\end{array}$ & $\begin{array}{c}\text { Laksi } \\
\text { kal }\end{array}$ & $\begin{array}{c}\text { Stru } \\
\text { ktur } \\
\text { al }\end{array}$ & $\begin{array}{c}\text { Non- } \\
\text { Faktua } \\
1\end{array}$ & $\begin{array}{c}\text { Kon } \\
\text { terfa } \\
\text { ktua } \\
1\end{array}$ \\
\hline 26 & 7 & 9 & 3 & - & 5 & 2 \\
\hline
\end{tabular}
terinspirasi dari lagu band Armada dengan judul yang sama. Dari dialog yang ada di novel tersebut banyak tuturan yang mengandung praanggapan. Jika pembaca novel mampu memahami praanggapan dengan baik maka pembaca akan semakin terhanyut dalam alur cerita.

Dalam menganalisa tentang praanggapan yang terdapat dalam dialog dalam novel Asal Kau Bahagia penulis menggunakan pendapat (Yule, 1996) Berdasarkan jenis, praanggapan dibagi menjadi 6 yaitu Eksistensial (existential), Faktual (Factive), Leksikal (Lexical), struktural (structural), Nonfaktual (Non-factive), Konterfaktual (counterfactual)

I. Praanggapan Faktual (Factive presupposition) Praanggapan jenis ini muncul dari informasi yang ingin disampaikan dinyatakan dengan tuturan yang berupa fakta yang diyakini kebenaranya.

\begin{tabular}{|c|c|}
\hline Data I & (hal. 2-3/AKB) \\
\hline Radha & : Sya... \\
\hline Tasya & : apaan sih? \\
\hline Radha & $\begin{array}{l}\text { : aku takut suatu hari kamu bakal } \\
\text { bosen sama aku dan ninggalin } \\
\text { aku }\end{array}$ \\
\hline Tasya & : kok bisa kepikiran seperti itu? \\
\hline Radha & $\begin{array}{l}\text { : aku kan tau kamu banyak yang } \\
\text { naksir }\end{array}$ \\
\hline Tasya & : kenapa musingin mereka? \\
\hline Radha & $\begin{array}{l}\text { : aku ga habis pikir, dari sekian } \\
\text { banyak cowo keren kamu malah } \\
\text { pilih cowo engga gaul, cupu. }\end{array}$ \\
\hline Tasya & $\begin{array}{l}\text { udah ah, engga usah mikirin } \\
\text { yang aneh-aneh yang penting } \\
\text { sekarang aku sama kamu. }\end{array}$ \\
\hline
\end{tabular}

Radha dan Tasya sedang menikmati kebersamaan di sebuah taman dengan hamparan rumput hijau. Tasya yang saat itu sedang menikmati sejuknya udara merebahkan tubuhnya di atas rumput sambil memejamkan mata, hal yang sama diikuti oleh Radha yang saat itu perasaannya sedikit gundah. Berbagai keraguan di benak Radha, dia ingin memastikan kembali tentang perasaan Tasya padanya. Hal ini terlihat dari tuturan Radha aku ga habis pikir, dari sekian banyak cowo keren kamu malah pilih cowo engga gaul, cupu. Dari tuturan tersebut jelas sekali menyiratkan sebuah keraguan. Tasyapun segera merespon dengan tuturan udah ah, engga usah mikirin yang aneh-aneh yang penting sekarang aku sama kamu. Dari tuturan tersebut, tersirat Tasya berusaha meyakinkan Radha bahwa semuanya baik-baik saja.

Mulai dari tuturan Radha aku takut suatu hari kamu bakal bosen sama aku dan ninggalin aku tuturan berikutnya aku kan tau kamu banyak yang naksir dan aku ga habis pikir, dari sekian banyak cowo keren kamu malah pilih cowo engga gaul, cupu. Melalui pengetahuan dari tuturan tersebut Radha menginginkan Tasya meyakinkannya kembali tentang alasan apa yang membuat dia memilih Radha. Dari tuturan tersebut menyiratkan bahwa Radha masih ragu akan sikap Tasya, dan Radha ingin Tasya jujur memberikan alasan yang pasti mengapa dia yang menjadi pilihan hati Tasya.

Melalui dialog Tasya dan Radha ada sebuah fakta atau kebenaran yang dapat diasumsikan, hal ini dapat diketahui melalui tuturan Tasya, udah ah, engga usah mikirin yang aneh-aneh yang penting sekarang aku sama kamu. Pernyataan Radha menjadi faktual karena dari tuturan tersebut dapat diketahui bahwa sebelum itu ada tuturan yang menurut Tasya "aneh-aneh" tuturan tersebut berasal dari Radha aku takut suatu hari kamu bakal bosen sama aku dan ninggalin aku,_tuturan tersebut muncul karena keraguan yang cukup mengganggu perasaan Radha dan hal ini juga muncul atas sebuah kebenaran atau fakta dari tuturan aku ga habis pikir, dari sekian banyak cowo keren kamu malah pilih cowo engga gaul, cupu. Dari tuturan di atas dapat diketahui bahwa Radha mengalami sebuah fakta dari apa yang dia rasa dan lihat yaitu Tasya cewe, cantik, pintar, popular sementara Radha cowo biasa, engga gaul, dan cupu. Dengan begitu praanggapan pada tuturan udah ah, engga usah mikirin yang aneh-aneh yang penting sekarang aku sama kamu merupakan praanggapan faktual. Praanggapan tipe ini juga terdapat pada data 3, 5, 6, 7, 8, II, 20, dan 24 .

\section{Praanggapan Lexical}

Menurut Yule, praanggapan leksikal merupakan bentuk dengan makna yang dinyatakan secara konvensional ditafsirkan dengan praanggapan bahwa suatu makna lain dipahami. Tuturan yang termasuk dalam praanggapan leksikal dinyatakan secara tersirat sehingga praanggapan tersebut diperoleh setelah tuturan.
Data I5
(ha1.99/AKB)
Andit : Eh...Tasya..., udah lama di sini?
Tasya 
Andit $\quad:$ hhmmm.... Udah dari tadi, tapi gw habis dari toilet dulu.

Radha : Dit! (Radha memberi isyarat agar Andit melakukan tugasnya)

Andit : (bergumam dalam hati) Ini tugas yang paling berat

Percakapan antara Tasya dan Andit terjadi saat mereka berada di ICU. Siang itu Tasya sedang duduk di sebelah ranjang, terbaring raga Radha dalam diam. Hadirlah Andit dengan arwah Radha yang mengikutinya. Hanya Andit yang mampu berkomunikasi dengan Radha. Oleh karena itu Radha ingin Andit membantunya untuk menanyakan kepada Tasya tentang siapa sebenarnya Erick, lakilaki yang dia lihat bersama Tasya di sebuah coffee shop, mencium dan memeluk erat Tasya. Namun karena hubungan pertemanan Andit dan Tasya tidak begitu baik, maka menjadi hal yang sulit bagi Andit untuk menanyakan semua hal tentang Erick pada Tasya. Saat Radha memberikan isyarat pada Andit untuk segera menghampiri Tasya dan menanyakan tentang Erick, Andit bergumam dalam hati Ini tugas yang paling berat.

Dari tuturan dalam hati yang dituturkan oleh Andit Ini tugas yang paling berat_ini merupakan sebuah kejujuran yang ingin dia sampaikan pada Radha. Hal ini diketahui dari pengetahuan bahwa hubungan pertemanan Andit dan Tasya tidak begitu baik, maka saat Radha meminta tolong pada Andit untuk berbicara ada Tasya menjadi sebuah hal yang berat untuk dilakukan. Namun karena Andit memahami benar apa yang sedang dialami oleh Radha maka dia hanya mampu bergumam di dalam hati. Hal ini dia lakukan untuk menjaga muka Radha dan juga persahabatan mereka.

Tuturan yang dihadirkan melalui gumaman Andit menghadirkan praanggapan leksikal. Praanggapan dengan tipe ini merupakan bentuk dengan makna yang dinyatakan secara konvensional ditafsirkan dengan praanggapan bahwa suatu makna lain dipahami. Berdasarkan dialog diatas sebelum adanya praanggapan leksikal didahului dengan pengetahuan bahwa antara Andit dan Tasya memiliki hubungan pertemanan yang tidak terlalu dekat, hal ini karena Andit menilai Tasya cewe yang jutek dan keras. Sementara Tasya memiliki penilaian terhadap Andit sebagai sosok yang memberikan pengaruh buruk bagi Radha. Hingga pada saat Andit memberikan isyarat pada Andit untuk segera bertanya tentang Erick pada Tasya hal ini menjadi sesuatu yang sangat berat, terlihat dalam tuturan Ini tugas yang paling berat. Dari tuturan Ini tugas yang paling berat. Memiliki tipe praanggapan leksikal. Praanggapan ini dapat diartikan secara leksikal atau konvensional yang ditafsirkan melalui suatu makna lain dipahami. Praanggapan yang muncul dari tuturan tersebut adalah sebelumnya Radha sudah banyak meminta pertolongan pada Andit sebagai seorang teman. Hal ini dapat diketahui dari tuturan yang paling berat berarti ada hal-hal lain sebelumnya yang membutuhkan bantuan dari Andit, tapi kali ini untuk mencari informasi dari Tasya merupakan hal atau tugas yang paling berat. Praanggapan leksikal juga terdapat pada data 2 dan 2 I.

\section{Praanggapan Eksistensial (Existential)}

Praanggapan ini menunjukan kepemilikan sesuatu, keberadaan sesuatu atau eksistensi dari pernyataan dalam tuturan.

Data 17 (hal. I00-I0I/AKB)

Di ruang ICU ada Tasya, Andit, tubuh radha yang terbaring, serta arwah Radha. Hp Tasya berbunyi "Tiiing" dari dalam tasnya. Tasya mengambil handphone dan membaca isi pesannya, mengetik balasan, lalu memasukannya kembali dalam tasnya.

Situasi tersebut di ruang ICU saat Tasya dan Andit menemani tubuh Radha yang belum juga siuman dari koma. Saat itu mereka tidak saling bercakap, hanya keheningan dan bunyi alat-alat bantu yang berada di samping ranjang yang menemani mereka. Sesaat terdengar suara hp milik Tasya berbunyi sesaat menunjukkan pesan masuk. Pesan itu dari Erick "Sya, kita jadi dinner nanti malam?" Tasya membalas pesan tersebut lalu memasukannya kembali kedalam tasnya.

Praanggapan eksistensial menunjukkan keberadaan atau sesuatu yang disampaikan melalui praanggapan. Hal ini terdapat pada tuturan dalam situasi berikut $\mathrm{Hp}$ Tasya berbunyi ... tiing. Praanggapan dari tuturan tersebut adalah sosok bernama Tasya ada, Tasya memiliki HP, dan jika saat itu hanya ada satu $\mathrm{Hp}$ yang berbunyi yaitu yang berasal dari dalam tas Tasya, maka tuturan tersebut dapat dinyatakan kebenarannya yaitu benar HP itu milik Tasya. Praanggapan eksistensial juga terdapat pada data 4, 9, I6, 22, 23, 26

4. Praanggapan Non-Faktual (Non-Factual)

Data I3 (hal. 94/AKB)

Andit : Lo kenal cowoknya?

Radha : (menggeleng kepala)

Andit : Lo yakin Dha? Mksud gue, Tasya emang sering jutek anaknya, tapi gue liat dia bukan tipe kayak gitu deh. Lo benerbener yakin... Tasya selingkuh?

Radha : Ya. Tasya betul-betul melakukannya. Selama ini gue 
berpikir hubungan gue sama Tasya baik-baik saja.... Selama ini, gue berikir dia sayang banget sama gue.

Percakapan di atas terjadi saat Radha dan Andit berada di rooftop rumah sakit tempat Radha dirawat. Mereka berdua memilih rooftop sebagai tempat yang aman untuk mereka ngobrol. Hal ini berkaitan dengan keadaan Radha yang sedang mengalami koma dan terpisahnya antara raga dan jiwa. Namun demikian Andit ternyata memiliki indra keenam, dengan kemampuannya itu Andit dapat berkomunikasi dengan jiwa Ardha. Jika mereka berdua mengobrol di tempat umum maka Andit akan menjadi bahan tertawaan atau bahkan dianggap gila karena terlihat tertawa dan berbicara sendiri. Berdasarkan dialog di atas, Radha dan Andit sedang membicarakan sesuatu. Radha mencurahkan segara kegalauan hatinya salah satunya kejadian yang baru saja dia alami yaitu melihat Tasya bertemu dengan pria bernama Erick di sebuah coffee shop. Radha sangat terpukul bahkan bertanya-tanya dalam hatinya apa yang salah dengan dirinya selama ini hingga Tasya bertemu pria selain dirinya.

Andit tidak bisa terlalu banyak berkomentar tentang hal ini, hanya merespon dengan bertutur Lo kenal cowoknya? Disusul kembali dengan tuturan Lo yakin Dha? Maksud gue, Tasya emang sering jutek anaknya, tapi gue liat dia bukan tipe kayak gitu deh. Lo bener-bener yakin... Tasya selingkuh? Andit berusaha untuk memahami perasaan Radha namun dia juga belum bisa memepercayai semua yang telah Radha ceritakan tentang Tasya dan cowo tersebut. Radhapun hanya menggelengkan kepala, karena dia juga tidak tau siapa pria itu dan apa penyebab dari semua itu. Namun Radha dengan yakin menjawab pertanyaan terakhir dari Andit Lo bener-bener yakin... Tasya selingkuh? Jawaban Radha singkat Ya._Jawaban ini seolah-olah merupakan kata terakhir yang pantas Radha tuturkan tentang apa yang sudah Tasya lakukan dibelakang dia.

Lalu Radha kembali bertutur lirih Selama ini gue berpikir hubungan gue sama Tasya baik-baik saja.... Selama ini, gue berpikir dia sayang banget sama gue. Tuturan ini seolah menyiratkan bahwa Radha begitu heran dan tidak percaya apa yang sudah Tasya lakukan. Melalui tuturan tersebut Radha menganggap bahwa selama ini hubungan keduanya baik-baik saja dan Tasya begitu menyayangi dan menerima segalanya kekurangannya. Dari tuturan tersebut jelas menyiratkan kesedihan dan kekecewaan di hati Radha. Ada sesuatu yang sudah terlupakan dalam hubungan mereka, ada sebuah rahasia yang ditutup rapat oleh Tasya tentang hubungannya dengan Erick, dengan pengetahuan tersebut Radha menganggap bahwa sudah tidak ada kejujuran dalam hubungan mereka lebih tepatnya dalam 6 bulan terakhir.

Melalui tuturan Radha Selama ini gue berpikir hubungan gue sama Tasya baik-baik saja.... Selama ini, gue berpikir dia sayang banget sama gue. Praanggapan yang muncul dari tuturan tersebut adalah hubungan Radha dan Tasya ada masalah atau tidak baik-baik saja dan Tasya tidak sepenuh hati menyayangi Radha. Dalam tuturannya Radha memunculkan praanggapan non-faktual karena tuturan tersebut memunculkan praanggapan mengenai keadaan yang tidak sesuai dengan kenyataan yaitu hubungannya ada masalah yaitu Tasya diam-diam sudah menjalani hubungan dengan pria lain bernama Erick selama enam bulan, praanggapan berikutnya muncul Tasya tidak sepenuhnya menyayangi Radha, hal ini didukung dengan pengetahuan bahwa Tasya telah membagi sayang dan cintanya untuk Erick. Oleh karena itu praanggapan hubungan gue baik-baik saja dan dia sayang banget sama gue bisa diasumsikan melalui tuturan yang kebenarannya masih diragukan dengan fakta yang disampaikan. Praanggapan non factual juga terdapat dalam data I0, I2, I8, dan I9

\section{Praanggapan Konterfaktual (Counter-factual)}

Data 25 (hal. I77/AKB)

Tasya tidak pernah mengungkapkan pikirannya ke Radha, karena Radha tidak akan mengerti. Apalagi Radha selalu bertanya kenapa Tasya mau pacaran dengannya. Jika Tasya berkata jujur ke Radha bahwa dia jenuh, itu hanya akan membuktikan keraguan Radha yang merasa Tasya tidak pernah benar-benar sayang padanya. Walaupun demikian Tasya tau dia tidak akan bisa menyembunyikan hubungannya dengan Erick selama-lamanya. Suatu hari Tasya harus memutuskan Radha.

Pikiran Tasya sesaat menerawang jauh kembali mengingat saat pertama kalinya bertemu Radha hingga mereka memutuskan untuk menjalin hubungan sebagai sepasang kekasih. Disaat yang bersamaan juga terlintas wajah Erick yang tiba-tiba hadir diantara mereka melalui pertemuan yang tidak disengaja. Seolah sosok Erick menjadi penyelamat Tasya dalam rasa jenuh dalam hubungannya dengan Radha. Erick seakan membuka sisi lain dari sebuah hubungan yang menyenangkan, romantic, dan seru. Radha baik, tidak pernah selingkuh namun semua itu ternyata tidak cukup kuat untuk menjadi alasan Tasya untuk tetap bertahan dengan Radha. Tasya berniat suatu saat akan mengatakan yang sejujurnya tentang dia dan Erick pada Radha. 
Sambil merias wajah cantiknya Tasya bertutur dalam hati Jika Tasya berkata jujur ke Radha bahwa dia jenuh, itu hanya akan membuktikan keraguan Radha yang merasa Tasya tidak pernah benar-benar sayang padanya. Hal ini sempat terlintas di pikiran Tasya karena telah beberapa kali Radha menuturkan keraguannya terhadap Tasya dengan terus menanyakan kenapa Tasya memilih Radha. Namun Tasya selalu dapat menenangkan Radha dengan selalu meyakinkan bahwa sekarang mereka telah jadian. Dari penggalan lamunan Tasya di atas sangat jelas bahwa Tasya telah menepikan kejujuran dalam hubungan mereka. Bagi Tasya saat itu kejujuran menjadi suatu hal yang sangat sulit untuk dituturkan. Berbagai pertimbangan dan keraguan mengganggu pikiran Tasya jika kejujuran itu dituturkan. Tasya merasa jika Tasya jujur akan hubungannya dengan Erick maka semua itu akan membuktikan bahwa kegalauan Radha selama ini benar.

Praanggapan konterfaktual merupakan praanggapan yang menghasilkan pemahaman yang berkebalikan dari pernyataannya atau kontradiktif. Dari penggalan lamunan Tasya di atas terdapat tuturan Jika Tasya berkata jujur ke Radha bahwa dia jenuh, itu hanya akan membuktikan keraguan Radha yang merasa Tasya tidak pernah benar-benar sayang padanya. Praanggapan yang muncul adalah Tasya belum mengatakan yang sebenarnya tentang hubungannya dengan Erick pada Radha. Praanggapan tersebut muncul dari kontradiksi kalimat dengan adanya penggunaan tuturan Jika Tasya berkata jujur ke Radha bahwa dia jenuh. Penggunaan kata "jika” membuat praanggapan yang kontradiktif dari tuturan yang disampaikan. Praanggapan konterfaktual juga muncul pada data I4

\section{Simpulan}

Penelitian pragmatik praanggapan dalam novel Asal Kau Bahagia karya Bernard Batubara memberikan pemahaman lebih tidak hanya sekedar alur cerita tetapi juga pesan lain yang tentunya ingin disampaikan oleh penulis karya tersebut. Penulis memperoleh 26 data yang mengandung praanggapan yang terdiri dari 9 data termasuk dalam praanggapan faktif, 3 data praanggapan leksikal, 7 data sebagai praanggapan 5 data praanggapan non-faktual, dan 2 data merupakan praanggapan konterfaktual.

Selain itu melalui beberapa praanggapan tersebut tersirat adanya pesan bahwa dalam setiap tuturan, tindakan akan selalu berkaitan dengan nilai kejujuran, hanya saja kejujuran tersebut dapat dituturkan atau hanya tertahan hanya sebagai niatan untuk dituturkan. Jika ini terjadi maka hanya prasangka dan dendam yang ada. Selain itu melalui kajian pragmatik, praanggapan, serta kejujuran ini penulis juga berharap hasil tulisan ini akan mampu memberikan sumbangan pemikiran terhadap masyarakat pembaca tentang pentingnya nilai sebuah kejujuran dalam persahabatan, percintaan, serta dalam masyarakat yang akhir-akhir ini sedikit memudar.

\section{Daftar Pustaka}

Andryanto, S.F., Andayani, Rohmadi, M. (20I4). Analisis praanggapan pada percakapan tayangan ". BASASTRA, 2, I-I 6 .

KBBI. (2008). Kamus Besar Bahasa Indonesia (keempat). Jakarta: PT Gramedia Pustaka Utama.

Kusmiyati, D. (2013, December). Nilai Kejujuran Dalam Pespektif Mahasiswa. Kompasiana.

Purwo, B. K. (1984). Deiksis dalam Bahasa Indonesia. Jakarta: Balai Pustaka.

Rahardi, R. K. (2005). Pragmatik Kesantunan Imperatif Bahasa Indonesia. Jakarta: Erlangga.

Retnosari, I. E. (20I4). Praanggapan dan Implikatur Dalam Mr. Pecut Pada Jawa Pos. Wahan Jurnal Ilmiah Sains Dan Pendidikan, 63, I5-20.

Sudaryanto, S. (2015). Metode dan Aneka Teknik Analisa Bahasa: Pengantar Penelitian Wahana Kebudayaan Secara Linguistis. Yogyakarta: Sanata Dharma University Press.

Suparno P, D. (2003). Pendidikan Budi Pekerti. Yogyakarya: Penerbit Kanisius.

Wijana, I.D.P, dan M. R. (2009). Analisis Wacana Pragmatik Kajiaan Teori dan Analisis. Surakarta: Yuma Pustaka.

Wijayanti, A. (2016). Presuposisi dan Implikatur Pada Stand Up Comedy Indonesia. Transformatika, Vol. 12, 46-59.

Yule, G. (1996). Pragmatics. Oxford: Oxford University Press 